\title{
MOROCCAN STRAWBERRY TREE (Arbutus Unedo L.) LEAVES: COMPARATIVE STUDY OF THE NUTRITIONAL VALUE AND MINERAL COMPOSITION
}

\author{
Zakaria Ait lhaj ${ }^{1,2}$, Farida Ait lhaj ${ }^{2}$, Khalid Taghzouti ${ }^{4}$, Younes Abbas ${ }^{3}$, Fatima Gaboun ${ }^{1}$, \\ Ghizlane Diria ${ }^{1}$, Aouatif Benali ${ }^{1}$, Rabha Abdelwahd ${ }^{1}$, Najat Hakam ${ }^{5}$, \\ Rahma Bchitou ${ }^{2}$, Khadija Bakhy ${ }^{1}$
}

\begin{abstract}
${ }^{1}$ National Institute of Agricultural Research (INRA), BP 6356, Rabat, Morocco
${ }^{2}$ Faculty of Sciences, Nanostructures Laboratory, Process Engineering and Environment, center of materials science, Mohammed V University, Rabat, Morocco. ${ }^{3}$ Polydisciplinary Faculty, Sultan Moulay Slimane University, BéniMellal, Morocco

${ }^{4}$ Team of Physiology and Physiopathology, Faculty of Sciences, Research Center in Genomics of Human Pathologies, Mohammed V University in Rabat, Morocco

${ }^{5}$ Center of Horticultural training. 1051, Crescent Pierre-Bédard, Laval (Quebec) H7E 1y8, Canada.
\end{abstract}

Received - August 14, 2021; Revision - November 03, 2021; Accepted - November 22, 2021

Available Online - December 30, 2021

DOI: http://dx.doi.org/10.18006/2021.9(6).734.744

KEYWORDS
Strawberry
Chemical composition
Livestock feed
Morocco
Variability

\begin{abstract}
Strawberry tree (Arbutus Unedo L.) is one of the evergreen trees that grow spontaneously in Moroccan forests. This tall shrub is traditionally used in grazing zones of some Moroccan areas, especially during the dry season, but its value in Morocco has still been underestimated. In this paper, the nutritional composition of A. unedo leaves sample collected from seven Moroccan regions has been assessed. For this, the leaves were dried, crushed, and chemically analyzed for their proximate composition, energetic value, total and reducing sugar, and mineral composition. Results of this study suggested that samples from BniAarouse (BA) region showed the highest contents of essential nutrients such as proteins, dietary fiber, ashes, and fat with average values of 7.53,17.89, 4.14, and $8.05 \mathrm{~g} / 100 \mathrm{~g}$ of dry weight, respectively, which positively influences its consumption by small ruminants. Cluster analysis based on surveyed parameters separated the strawberries individuals into four distinct groups, providing a high variability among and within studied locations. That could be related to the diversity of the edaphoclimatic conditions between regions and to the genetic effect. The results of the present study highlighted the potential use of leaves as livestock feed, with intermediate quality, and promotes their optimal cultivation and subsequent domestication in Morocco.
\end{abstract}

* Corresponding author

E-mail: aitlhajzakaria.smc@gmail.com (Zakaria Ait lhaj)

Peer review under responsibility of Journal of Experimental Biology and Agricultural Sciences.

Production and Hosting by Horizon Publisher India [HPI] (http://www.horizonpublisherindia.in/).

All rights reserved.
All the articles published by Journal of Experimental Biology and Agricultural Sciences are licensed under a Creative Commons Attribution-NonCommercial 4.0 International License Based on a work at www.jebas.org.

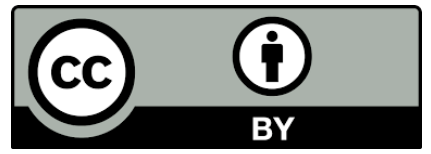




\section{Introduction}

The Arbutus unedo L. (A. unedo), is a small Mediterranean tree belonging to the Ericaceae family (Santiso Carral, 2015). It is found in many Moroccan regions, under different names, as Assisnou in Amazigh or Bakhanou in Arabic. The Mediterranean climate is one of the best climates for A. unedo growth. Further, the climate is a very important parameter due to its impact on the production rate of the species and their nutritional quality (Penuelas et al., 2008). In addition, soil also has a significant influence on the quality and yield of this plant, with this respect, this shrub prefers to grow in siliceous and acidic soil with a $\mathrm{pH}$ between 4 and 7 (Özcan \& Hacıseferoğulları, 2007). In Morocco, it was reported that $A$. unedo trees have significant resistance to harsh environmental conditions that could be related to their ability to grow in several types of soils with different physicochemical properties. Furthermore; the mineral composition of these tree leaves is also affected by the soil organic matter and $\mathrm{pH}$ (Ait lhaj et al., 2021b).

A. unedo is characterized by slow growth; reach up $9-12 \mathrm{~m}$ in height, the leaves $(4.5-12 \mathrm{~cm})$ are in persistent color, alternate, simple, oblanceolate, short-stalked, and toothed. While the flowers are characterized by a mixture of white and green color; they are bell-shaped, lobes recurved, and honey-scented (Celikel et al., 2008). The flowering phase starts from the end of September to December to avoid summer drought. The fruits are dark red, spherical with a diameter of $1.5-2 \mathrm{~cm}$ (Delgado-Pelayo et al., 2016).

Based on the leaves' chemical and mineral compositions the aerial parts of A. unedo constitute the principal diet of goats in Oued
Laou valley Morocco (INRA, 2011). The great energizing value of this shrub in different phenological stages provides suitable shreds of evidence for its uses as livestock feed during the dry summer. Unfortunately, the use of shrubs often remains limited due to the insufficient information and high concentration of some antinutritional compounds such as tannins and saponins (Rogosic et al., 2006; Udo et al., 2018). According to Rogosic et al. (2006), the consumption of these species along with feed additives such as activated carbon and calcium hydroxide has a potent effect on the availability of bioactive compounds in the animal organism (by decreasing the absorption of these compounds or increasing their elimination).

Therefore, the present study aimed to enhance the utilization and valorization of A. unedo in Morocco, as an edible plant for small ruminants feeding. Mainly, this study was carried out to establish the variability in protein, dietary fibers, ashes, mineral, and chemical composition of A. unedo leaves as per the harvest location.

\section{Materials and methods}

\subsection{Plant material and experimental areas}

Almost $1 \mathrm{Kg}$ of Strawberry-tree leaves were collected in November and December 2017 from 15 different stations including OULMES (OUL: 2 stations), OUJDA (OUJ: 2 stations), CHEFCHAOUEN (CH: 3 stations), BENI MELLAL (BM: 2 stations), BNI AAROUSS (BA: 3 stations), SOUK EL KOLLA (SQ: 2 stations), SIDI BETTACHE (SB: 1 station) that covering 7 different localities of Morocco (Figure 1, Table 1). In total, 120 samples were collected, with the following distribution (i) $37.5 \%$

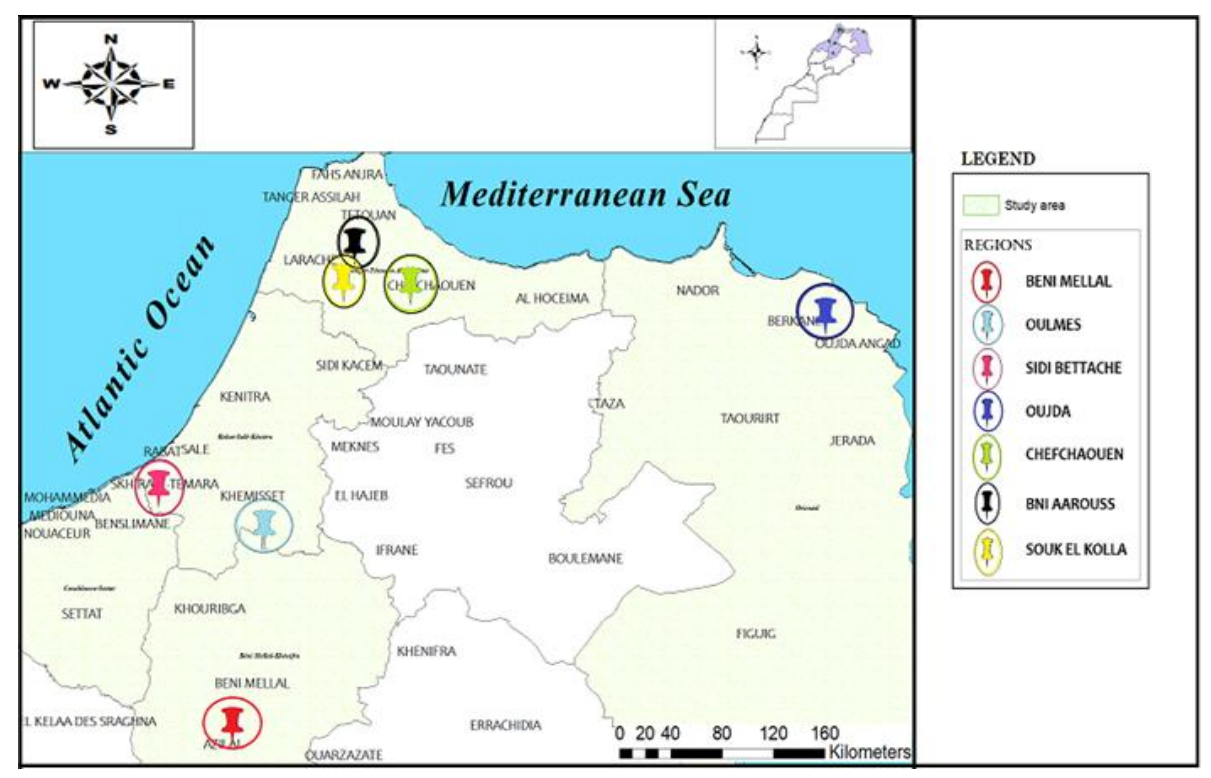

Figure 1 Harvest locations of Arbutus unedo in Moroccan study area

Journal of Experimental Biology and Agricultural Sciences http://www.jebas.org 
Table 1 Main ecological and geographical traits of the seven Moroccan regions of A. unedo.

\begin{tabular}{|c|c|c|c|c|c|}
\hline Regions & Geographical distribution & Bioclimatic zone & Stations & Number of samples \& codes & Altitude (m) \\
\hline \multirow{2}{*}{ OUL } & \multirow{2}{*}{ Central Plateau } & \multirow{2}{*}{ Sub-humid } & $\mathrm{AZ}$ & 6(AZ1-AZ6) & 1180 \\
\hline & & & Bs & 8 (Bs1- Bs8) & 1180 \\
\hline \multirow{2}{*}{ OUJ } & \multirow{2}{*}{ North Plateau } & \multirow{2}{*}{ Semi-arid } & $\mathrm{TF}$ & 15 (TF1- TF15) & 785 \\
\hline & & & Osy & 7 (Osy1-Osy7) & 1066 \\
\hline \multirow{3}{*}{$\mathrm{CH}$} & \multirow{3}{*}{ Western Rif } & \multirow{3}{*}{ Sub-humid } & Hch & 7 (Hch1- Hch7) & 698 \\
\hline & & & Dt & 6(Dt1- Dt6) & 384 \\
\hline & & & $\mathrm{Ta}$ & $3(\mathrm{Ta} 1-\mathrm{Ta} 3)$ & 453 \\
\hline \multirow{2}{*}{$\mathrm{BM}$} & \multirow{2}{*}{ Middle Atlas } & \multirow{2}{*}{ Sub-humid } & Agh & 11(Agh1- Agh11) & 1260 \\
\hline & & & $\mathrm{BL}$ & 9(BL1- BL9) & 1167 \\
\hline \multirow{3}{*}{ BA } & \multirow{3}{*}{ North West } & \multirow{3}{*}{ Sub-humid } & $\mathrm{Ja}$ & $10(\mathrm{Ja} 1-\mathrm{Ja} 10)$ & 527 \\
\hline & & & Mya & 3 (Mya1- Mya3) & 444 \\
\hline & & & Dazia & 5 (Dazia1- Dazia5) & - \\
\hline \multirow{2}{*}{ SQ } & \multirow{2}{*}{ North West } & \multirow{2}{*}{ Sub-humid } & $\mathrm{Kh}$ & 5 (Kh1- Kh5) & 340 \\
\hline & & & $S$ & $6(\mathrm{~S} 1-\mathrm{S} 6)$ & 300 \\
\hline SB & Central Plateau & Semi-arid & $\mathrm{Bn}$ & 19 (Bn1- Bn19) & 246 \\
\hline
\end{tabular}

"-" missed data.

of the samples from the Northern region (SQ, BA, and $\mathrm{CH}$ ); (ii) 27.5\% of samples from Central Morocco (SB and OUL); (iii) $18.3 \%$ of samples from the oriental region (OUJ) and $16.7 \%$ of samples from the Middle Atlas (BM), (Table 1). The Specimens of the collected plants were taxonomically identified by the removed taxonomist Prof. Hamid Khamar, Department of Botany and Plant Ecology, National Scientific Institute of Rabat. Voucher specimens from each locality were kept at the Herbarium of the National Institute of Agriculture Research (INRA), and another was deposited in the National Herbarium of Scientific Institute of Rabat and registered under the number-code RAB111500.

\subsection{Analytical methods}

\subsubsection{Nutritional value and chemical composition analysis}

Dry matter and ash contents of leaf samples were evaluated according to the Association of Official Analytical Chemists (AOAC) method (AOAC, 1990). The Total $\mathrm{N}$ was determined by the macro-Kjeldahl method (Chemists, 1999), then converted to crude protein (CP) using the conversion factor of 6.25. Briefly, the total $\mathrm{N}$ was quantified by the digestion of $1 \mathrm{~g}$ of leaf powder with concentrated sulfuric acid, allowing ammonium hydroxide production. The ammonium is then trapped with boric acid in a basic medium $(\mathrm{NaOH} N / 10)$. Finally, the ammonia (as ammonium borates) is titrated with concentrate $\mathrm{HCl}$.

\subsubsection{Estimation of fat content}

Fat content was determined according to the AOAC method 991.36 by a soxhlet extraction system (AOAC, 2000). Briefly, $5 \mathrm{~g}$ of the powder was placed in a flask and extracted with ethyl ether at $45{ }^{\circ} \mathrm{C}$ for $6 \mathrm{hrs}$ by a Soxhlet liquid/solid extractor. The extract was then dried by placing the flask in an oven at $102^{\circ} \mathrm{C}$ until it reach a constant weight (1-2 hours) than it was cooled in a desiccator and weighed. The fat content recovered in the sample is determined by the following formula:

$$
\% \text { Crude fat }=(\mathrm{W} 2-\mathrm{W} 1) \times 100 / \mathrm{S}
$$

Where:

W1: Weight of empty flask (g); W2: Weight of flask and extracted fat $(\mathrm{g}) ; \mathrm{S}$ : Weight of sample $(5 \mathrm{~g})$

\subsubsection{Determination of crude fiber}

The crude fiber content was also quantified according to the AOAC method (AOAC, 2005). The method is based on the degradation of non-cellulosic compounds by sulfuric acid and sodium hydroxide. After hydrolysis, the residue is dried for 16 hours at $105^{\circ} \mathrm{C}$, then cooled and weighed. Finally, the final residue is incinerated at $500{ }^{\circ} \mathrm{C}$ for $4 \mathrm{hrs}$ to remove the ash fraction and this was followed by the cooling and weighing. 


\subsubsection{Total carbohydrates and energetic value}

Total carbohydrates content was calculated by using the following formula: Total carbohydrates $(\%)=100-(\mathrm{g}$ moisture $+\mathrm{g}$ protein + $\mathrm{g}$ fat $+\mathrm{g}$ ash), (Barros et al., 2008), and the energetic value of leaves samples was estimated by the sum of the energetic values associated with each nutrient compound (protein, carbohydrates, and lipid) according to the equation: Energy $(\mathrm{kcal})=4 \mathrm{x}$ (g protein $+\mathrm{g}$ carbohydrate) $+9 \mathrm{x}$ (g lipid), (Barros et al., 2008).

\subsubsection{Total and reducing sugar}

Total sugar content was spectrophotometrically determined according to the described protocol of Dubois et al. (1956). For this, $1 \mathrm{ml}$ of the extract solution $[1 \mathrm{~g}$ of leaves powder extracted with $40 \mathrm{~mL}$ of ethanol/water solution $(80 / 20 \mathrm{~V} / \mathrm{V})]$ was mixed with $1 \mathrm{~mL}$ of phenol reagent $(5 \%)$ and $5 \mathrm{~mL}$ of sulfuric acid. The mixture was shaken vigorously and kept in the water bath at $40{ }^{\circ} \mathrm{C}$ for $30 \mathrm{~min}$ and the optical density was measured at $490 \mathrm{~nm}$ in UV/Vis Spectrometer (Model UV2601 UV/VIS/Rayleigh, BRAIC, china).

Reducing sugar content was quantified by using dinitrosalicylic acid (DNS) reagent at an optical density of $575 \mathrm{~nm}$, and a double beam UV/Vis Spectrometer (Model UV2601 UV/VIS/Rayleigh, BRAIC, China), according to the method described by Miller (Miller, 1959). Briefly, $3 \mathrm{~mL}$ of the extract solution was mixed with $3 \mathrm{~mL}$ of DNS solution, and the mixture and shaken vigorously, this mixture was kept in a water bath at $90{ }^{\circ} \mathrm{C}$ for 15 min. $1 \mathrm{~mL}$ of potassium solution $(\mathrm{Na}, \mathrm{K})$ was added before reading the absorbance of the mixture.

The total sugar and reducing sugar contents were determined against a standard glucose calibration curve (concentration range of 0.004 to $1 \mathrm{mg} / \mathrm{g}$ and 0.06 to $1 \mathrm{mg} / \mathrm{g}$, respectively).

\subsubsection{Mineral elements}

The mineral composition was determined by incineration of $1 \mathrm{~g}$ in a muffle furnace for $6 \mathrm{hrs}$ at $500{ }^{\circ} \mathrm{C}$ and extracted with saturated $\mathrm{HCl}$. The volume of the mixture is then adjusted to $100 \mathrm{ml}$ with distilled water to determine the mineral contents. $\mathrm{Mg}, \mathrm{Fe}, \mathrm{Mn}, \mathrm{Zn}$, and $\mathrm{Cu}$ minerals content were determined by atomic absorption spectrophotometry in flame, air-acetylene (58B AA spectrophotometer/Agilent/California/USA)(Saleem et al., 2021). Sodium $(\mathrm{Na}+)$ and potassium $(\mathrm{K}+)$ were measured using a flame photometer (Rajagopal \& Mathew, 2020). Phosphorus (P) level was determined by using the colorimetric method, based on the reaction of ammonium molybdate with the ascorbic acid and antimony (Kováčik et al., 2009). The absorption was measured at $825 \mathrm{~nm}$ with a UV-visible spectrophotometer (Model 6405 UV/VIS spectrometer/Jenway/UK).

\subsection{Statistical analysis}

Data are expressed as the mean $\pm \mathrm{SE}$ of all measurements carried out in duplicate. They have been subjected to analysis of variance (ANOVA) followed by the Duncan test at $\mathrm{p}<0.05$ to determine the geoclimatic effect on the chemical composition of A. unedo leaves. ANOVA and Principal Components Analysis (PCA) were conducted using SAS (version 9.1) and GenStat software (18th edition) successively. PCA and Factorial Discriminant Analysis (FDA) was carried out to determine the different groups to which the different samples refer. Hierarchical clustering was performed according to the Complete Linkage Method using Euclidian Similarity.

\section{Results and discussion}

The results of the current study highlighted the nutritional value of A. unedo leaf samples in various localities. With distinct ecological and edaphically features explored for the first time, to give a unique insight into the nutritional value of strawberry tree leaves. The current study constitutes the first step for a future-wide valorization of this species in animal feed as well in the production of new functional products. Results of the study revealed that Moroccan A. unedo grows under different wild bioclimatic zones at altitudes ranging from 246 to $1260 \mathrm{~m}$. All samples are collected between November and December of 2017 to eliminate the seasonal effect. However, 120 samples were collected from individual trees at 15 locations in seven regions; covering most of the species natural habitats in Morocco (Figure 1).

\subsection{Nutritional composition of A. unedo leaves}

The nutritional value of the A. unedo leaves collected from 7 different Moroccan regions is presented in Table 2. Statistical analysis of nutritional composition revealed noticeable spatial variation in nutritive value of $A$. unedo leaves. The bioclimatic differences among the seven investigated regions seem to have a significant effect on the chemical content. The dry matter content of leaves differed significantly among regions $(P<0.001)$, and it was ranging from 88.97 to $94.83 \%$ for $\mathrm{BA}$ and $\mathrm{CH}$ regions, respectively. The fat content of $A$. unedo leaves varied significantly between regions, which is mostly due to several parameters such as particle size of leaf powder, moisture, nature of the solvent, the extraction method, heterogeneity, geographical distribution, climatic conditions, and edaphic characteristics of the soil(Gaouar, 2011).

As depicted in Table 1 and Table 2, it is noticeable that the variation in lipid level in samples from different regions is related mainly to altitude, where individuals from the high altitude region (BM) have the highest lipid content $(10.47 \mathrm{~g} / 100 \mathrm{~g})$, and individuals from the low altitude regions ( $\mathrm{SQ}$ and $\mathrm{SB}$ ) have the 
lowest levels (7.78 and $7.27 \mathrm{~g} / 100 \mathrm{~g}$, respectively), which has been also proved in the study reported by Boussalah et al. (2018) when conducted a study on the composition of A. unedo fruits nutrients.

Crude protein is a key factor to discuss the quality of forage (Amiri, 2012), as mentioned in table 2, the protein content in $A$ unedo leaves (average value of $7.17 \mathrm{~g} / 100 \mathrm{~g}$ of DW) was within the range of other works, which reported content of 7.2 and 6.8 g/100 g of DW (Tisserand \& Faurie, 1994; Boubaker et al., 2004). However, a study conducted by Parissi et al. (2018) showed higher protein content (10.8 g/100 g of DW) as compared to this study. Generally, it was reported that protein content in A. unedo leaves was found to exceed the required demands of small ruminants (Parissi et al., 2018).

Strawberry-tree leaves are considered as a rich source of carbohydrate (Table 2) that allows a high energetic value (an average energetic value of $392.54 \mathrm{Kcal} / 100 \mathrm{~g} \mathrm{DW}$ ). Indeed, the important amount of carbohydrate proved in the current study agreed with the proximate analysis of $A$. unedo leaf samples from Portugal, which found that this shrub contains $73.21 \mathrm{~g} / 100 \mathrm{~g} \mathrm{DW}$ of carbohydrate (Nunes, 2017). The higher carbohydrates content in plants was explained in several studies by the fact of plant storage of this compound in surfeit, and only a small amount is deployed in the first stages of growth (Canadell \&López-Soria 1998). Therefore, Moroccan A. unedo leaves have a higher conten of carbohydrates (average value of $71.7 \mathrm{~g} / 100 \mathrm{~g}$ of DW) than the A. unedo fruit samples collected from Algeria (an average value of $13.93 \mathrm{~g} / 100 \mathrm{~g}$ ). This difference might be related to the content of dry matter in each part of the plant. Noted that the average value of dry matter determined for the A. unedo fruit collected from Algeria was $29.06 \%$ (Boussalah et al., 2018), while in the current study, the leaves samples present a dry matter content of $94.82 \%$ as a mean value.

Dietary fiber, the abundant component of total carbohydrates (25
$\%$ ), was shown in an average value of $17.06 \mathrm{~g} / 100 \mathrm{~g} \mathrm{DW}$, and this was reported higher than the content $(16.5 \mathrm{~g} / 100 \mathrm{~g}$ DW) reported by Tisserand \& Faurie (1994). It is suggested by several studies that the potential use of $A$. unedo leaves alongside others in animal feed, it presented considerable amounts of NDF (Neutral Detergent Fiber) and ADL (Acid Detergent Lignin), with a value of 43.6 and $11.5 \mathrm{~g} / 100 \mathrm{~g}$ respectively (Ammar et al., 2005; Parissi et al., 2018). Also, dietary fiber has a great effect on the effectiveness of phenolic compounds, especially during their passage through the digestive tract, by protecting their physicochemical structure, and provides this species with the particularity of being an important source of polyphenols, allowing its potential use as a functional food in addition to its high nutritional value (Jardim et al., 2017; Stephenie et al., 2020).

Concerning the total and reducing sugar, significant differences were reported between the various regions (Table 2). This variability might be depending on the plant age, phase of the vegetative cycle, genetic factors, and also depends on the exposure of various pedoclimatic conditions, and geographical distribution (Ruiz-Rodríguez et al., 2011). Significant variations in reducing sugar contents were observed between surveyed locations, particularly in $\mathrm{CH}$ and SQ samples (recorded the highest and the lowest contents, respectively), which could be explained by the bioclimatic zone differences related to each locality. Indeed, the $\mathrm{CH}$ region presents a humid bioclimatic zone that promotes the decomposition of a part into reduced sugars.

The chemical variability found on nutritive value from such a large number of trees of wild A. unedo grown in different areas of Morocco confirms the high chemical variability reported for the same genus by many authors (Takrouni \& Boussaid, 2010; Gündoğdu et al., 2018; Zitouni et al., 2020).

Samples from BM and OUJ that have the highest nutritional value belong to the subhumid bioclimatic stage and high altitude (1167-

Table 2 Nutritional value and $\mathrm{pH}$ content of $A$. unedo leaves in the studied regions

\begin{tabular}{|ccccccccccc|}
\hline Regions & $\begin{array}{c}\text { Moisture } \\
(\mathrm{g} / 100 \mathrm{~g} \mathrm{DW})\end{array}$ & $\begin{array}{c}\text { Fat } \\
(\mathrm{g} / 100 \mathrm{~g} \mathrm{DW})\end{array}$ & $\begin{array}{c}\text { Ash } \\
(\mathrm{g} / 100 \mathrm{~g} \text { DW })\end{array}$ & $\begin{array}{c}\text { Protein } \\
(\mathrm{g} / 100 \mathrm{~g} \mathrm{DW})\end{array}$ & $\mathrm{pH}$ & $\begin{array}{c}\text { Total sugars } \\
(\mathrm{g} \mathrm{EG} / \\
100 \mathrm{~g} \text { DW })\end{array}$ & $\begin{array}{c}\text { Reducing } \\
\text { sugars } \\
(\mathrm{g} \mathrm{EG} / \\
100 \mathrm{~g} \text { DW })\end{array}$ & $\begin{array}{c}\text { Dietary fiber } \\
(\mathrm{g} / 100 \mathrm{~g} \text { DW })\end{array}$ & $\begin{array}{c}\text { Carbohydrate } \\
\mathrm{s}(\mathrm{g} / 100 \mathrm{~g} \\
\mathrm{DW})\end{array}$ & $\begin{array}{c}\text { Energetic } \\
\text { value }\end{array}$ \\
\hline OUL & $10.47 \pm 0.06^{\mathrm{b}}$ & $8.45 \pm 0.13^{\mathrm{c}}$ & $3.92 \pm 0.1^{\mathrm{d}}$ & $6.54 \pm 0.07^{\mathrm{e}}$ & $4.53 \pm 0.01^{\mathrm{f}}$ & $18.43 \pm 0.50^{\mathrm{e}}$ & $2.79 \pm 0.13^{\mathrm{e}}$ & $18.57 \pm 0.35^{\mathrm{b}}$ & $70.6 \pm 0.19^{\mathrm{d}}$ & $384.7 \pm 0.7^{\mathrm{e}}$ \\
\hline OUJ & $8.07 \pm 0.24^{\mathrm{f}}$ & $8.55 \pm 0.15^{\mathrm{c}}$ & $3.92 \pm 0.13^{\mathrm{d}}$ & $7.73 \pm 0.1^{\mathrm{a}}$ & $5.42 \pm 0.02^{\mathrm{a}}$ & $23.52 \pm 0.64^{\mathrm{c}}$ & $5.25 \pm 0.27^{\mathrm{b}}$ & $18.89 \pm 0.16^{\mathrm{a}}$ & $71.70 \pm 0.29^{\mathrm{c}}$ & $394.77 \pm 1.36^{\mathrm{c}}$ \\
\hline CH & $5.17 \pm 0.1^{\mathrm{g}}$ & $9.6 \pm 0.18^{\mathrm{b}}$ & $3.83 \pm 0.07^{\mathrm{e}}$ & $5.41 \pm 0.1^{\mathrm{g}}$ & $4.47 \pm 0.03^{\mathrm{f}}$ & $26.14 \pm 0.47^{\mathrm{a}}$ & $6.96 \pm 0.30^{\mathrm{a}}$ & $16.87 \pm 0.19^{\mathrm{e}}$ & $75.97 \pm 0.18^{\mathrm{a}}$ & $411.97 \pm 1.27^{\mathrm{a}}$ \\
\hline BM & $9 \pm 0.18^{\mathrm{e}}$ & $10.65 \pm 0.15^{\mathrm{a}}$ & $4.77 \pm 0.14^{\mathrm{a}}$ & $7.24 \pm 0.15^{\mathrm{c}}$ & $4.96 \pm 0.02^{\mathrm{b}}$ & $24.13 \pm 0.71^{\mathrm{b}}$ & $5.26 \pm 0.23^{\mathrm{b}}$ & $17.44 \pm 0.27^{\mathrm{d}}$ & $69.77 \pm 0.24^{\mathrm{e}}$ & $403.96 \pm 1.13^{\mathrm{b}}$ \\
\hline BA & $11.02 \pm 0.1^{\mathrm{a}}$ & $8.05 \pm 0.14^{\mathrm{d}}$ & $4.14 \pm 0.11^{\mathrm{c}}$ & $7.53 \pm 0.15^{\mathrm{b}}$ & $4.7 \pm 0.02^{\mathrm{e}}$ & $18.56 \pm 0.52^{\mathrm{e}}$ & $3.65 \pm 0.22^{\mathrm{d}}$ & $17.89 \pm 0.11^{\mathrm{c}}$ & $69.53 \pm 0.19^{\mathrm{f}}$ & $379.59 \pm 1.1^{\mathrm{g}}$ \\
\hline SQ & $9.77 \pm 0.1^{\mathrm{c}}$ & $7.78 \pm 0.17^{\mathrm{e}}$ & $4.38 \pm 0.18^{\mathrm{b}}$ & $6.29 \pm 0.11^{\mathrm{f}}$ & $4.81 \pm 0.02^{\mathrm{d}}$ & $20.34 \pm 0.42^{\mathrm{d}}$ & $2.44 \pm 0.24^{\mathrm{f}}$ & $16.57 \pm 0.23^{\mathrm{f}}$ & $71.76 \pm 0.19^{\mathrm{c}}$ & $382.29 \pm 1.25^{\mathrm{f}}$ \\
\hline SB & $9.42 \pm 0.27^{\mathrm{d}}$ & $7.27 \pm 0.09^{\mathrm{f}}$ & $3.29 \pm 0.08^{\mathrm{f}}$ & $7.05 \pm 0.05^{\mathrm{d}}$ & $4.89 \pm 0.02^{\mathrm{c}}$ & $14.80 \pm 0.57^{\mathrm{f}}$ & $4.31 \pm 0.21^{\mathrm{c}}$ & $13.08 \pm 0.31^{\mathrm{g}}$ & $72.96 \pm 0.32^{\mathrm{b}}$ & $385.54 \pm 1.03^{\mathrm{d}}$ \\
\hline
\end{tabular}

Data are expressed as means \pm Standard Error (SE); All measurements are analyzed in duplicate $(\mathrm{n}=2)$; SE: Standard Error; The values in the same column with different letters differs significantly at $p<0.05$. 
$1180 \mathrm{~m}) . \mathrm{CH}$ region has a humid climate and intermediate elevation (384-698 m) which favour the nutrient deposition and this might be a reason that samples collected from this region have significantly higher nutrient content except for protein. SB has a semiarid bioclimatic condition and low elevation $(246 \mathrm{~m})$ and almost all samples collected from this region have a lower level of the majority of investigated compounds. However, the sample collected from the subhumid OUL bioclimatic region and high altitude $(1180 \mathrm{~m})$, had a moderate nutritional value.

\subsection{Mineral composition}

The contents of seven minerals were investigated and quantified for 120 samples collected from seven regions and expressed as mean contents in $\mathrm{mg} / 100 \mathrm{~g}$ of dry weight (Table 3). Potassium is the predominant mineral $(358.08 \mathrm{mg} / 100 \mathrm{gDW})$ of Moroccan $A$. unedo leaves, followed by phosphorus ( $94.61 \mathrm{mg} / 100 \mathrm{~g} \mathrm{DW})$. Results are in agreement with the findings of previous studies of García et al. (2011) and Asmaa et al. (2021) those have reported substantial potassium content (1413 and $1743 \mathrm{mg} / 100 \mathrm{~g} \mathrm{DW})$ and phosphorus (167.8 and $181.9 \mathrm{mg} / 100 \mathrm{~g}$ DW) (García et al., 2011; Asmaa et al., 2021). Higher variability was registered in all mineral amounts and all samples among and within the surveyed regions; providing a considerable percentage of the coefficient of variation $(\mathrm{CV})$, ranging from almost $29 \%$ for Zinc and $99.46 \%$ for copper, which shows the effect of plant origin on the mineral composition of A. unedo leaves (Table 3).

Concerning the microelement, including iron $(20.84 \mathrm{mg} / 100 \mathrm{~g})$, manganese (2.27 mg /100g), and zinc (2.27 mg /100g),(Table 4), the results were in line with those reported by others $(25 ; 2.7$ and $8.5 \mathrm{mg} / 100 \mathrm{~g}$ in iron, manganese, and zinc, respectively) (García et al., 2011). It was reported that the variability in mineral content of leaves might be described by the soil nutrient level that is among the dominant factor affecting leaf nutrient value ( $\mathrm{Li} \&$ Mazza, 1999). It is noticeable that this is the first study that focused on the mineral contents of leaves sampled from individual trees and different Moroccan regions, except the work which has confirmed the potent mineral content on leaves that are endowed by great health-promoting activity (Mrabti et al., 2017).

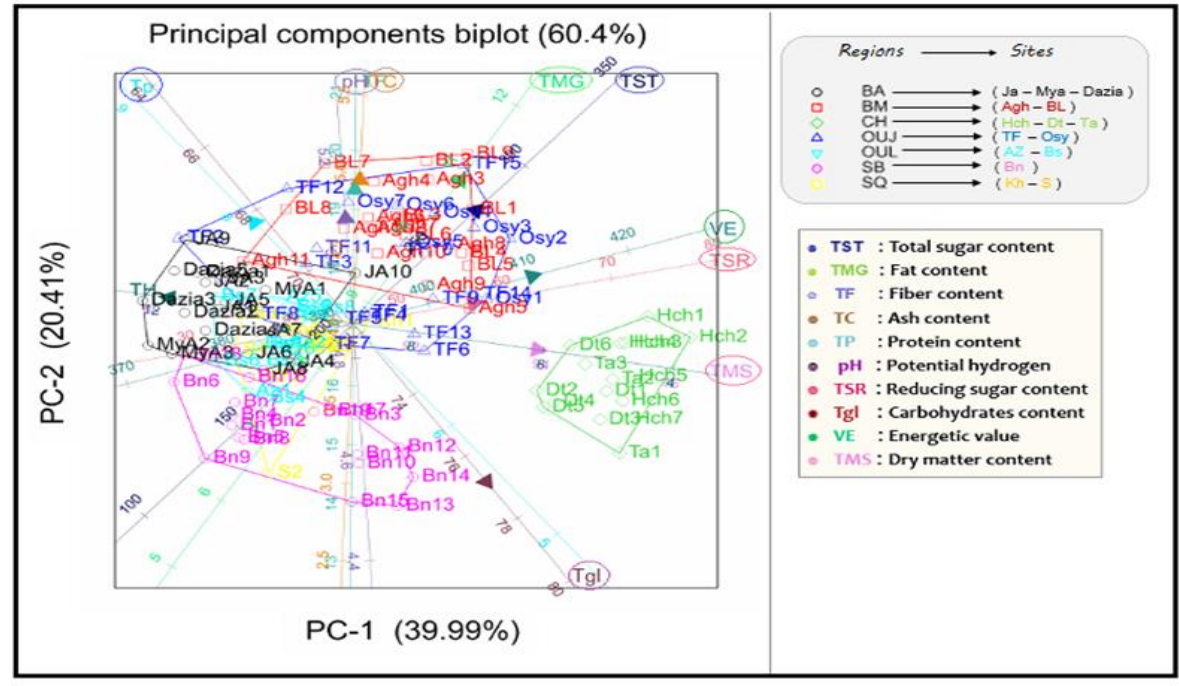

Figure 2 Distribution of variable vectors by trait biplot in the plane of PCA of nutrients content of A. unedo leaves

Table 3 Mineral composition average of Moroccan A. unedo Leaves

\begin{tabular}{|c|c|c|c|c|c|c|}
\hline Nutrient Composition & $\begin{array}{c}\text { Parameters } \\
(\mathrm{mg} / 100 \mathrm{~g} \mathrm{DW})\end{array}$ & $\begin{array}{c}\text { Number of } \\
\text { samples }\end{array}$ & Mean \pm SE & Min & $\operatorname{Max}$ & $\mathrm{CV}(\%)$ \\
\hline \multirow{3}{*}{ Macroelements } & $\mathrm{P}$ & 120 & $94.61 \pm 2.11$ & 27.15 & 184.73 & 34.55 \\
\hline & K & 120 & $358.08 \pm 9.59$ & 72 & 472 & 41.49 \\
\hline & $\mathrm{Na}$ & 120 & $33.03 \pm 0.87$ & 10 & 74 & 40.84 \\
\hline \multirow{4}{*}{ Microelements } & Mn & 120 & $2.27 \pm 0.09$ & 0.4 & 7.2 & 63.90 \\
\hline & $\mathrm{Fe}$ & 120 & $20.84 \pm 0.52$ & 2.4 & 64.4 & 39.15 \\
\hline & $\mathrm{Zn}$ & 120 & $11.18 \pm 0.20$ & 4.2 & 20.1 & 29.00 \\
\hline & $\mathrm{Cu}$ & 120 & $0.51 \pm 0.03$ & 0 & 2.9 & 99.46 \\
\hline
\end{tabular}

Journal of Experimental Biology and Agricultural Sciences http://www.jebas.org 
Table 4 Mineral composition of A. unedo leaves expressed in mg per $100 \mathrm{~g}$

\begin{tabular}{|c|c|c|c|c|}
\hline \multirow{2}{*}{ Region } & \multicolumn{4}{|c|}{ Macroelements } \\
\hline & $\mathrm{P}$ & \multicolumn{2}{|c|}{ K } & $\mathrm{Na}$ \\
\hline OUL & $71.25 \pm 3.17^{\mathrm{c}, \mathrm{d}}$ & \multicolumn{2}{|c|}{$521.82 \pm 25.75^{\mathrm{a}}$} & $29.5 \pm 2.24 \mathrm{c}$ \\
\hline OUJ & $74.35 \pm 2.05^{\mathrm{cd} d}$ & \multicolumn{2}{|c|}{$391.16 \pm 19.1^{b}$} & $39.32 \pm 1.91^{b}$ \\
\hline $\mathrm{CH}$ & $66.41 \pm 2.91^{\mathrm{d}}$ & \multicolumn{2}{|c|}{$320.62 \pm 16.1^{\mathrm{c}}$} & $25 \pm 0.96^{\mathrm{c}, \mathrm{d}}$ \\
\hline BM & $134.64 \pm 2.53^{a}$ & \multicolumn{2}{|c|}{$215.85 \pm 20.04^{\mathrm{d}}$} & $21.65 \pm 1.27^{\mathrm{d}}$ \\
\hline BA & $80.84 \pm 1.73 c$ & \multicolumn{2}{|c|}{$431 \pm 18.35^{\mathrm{b}}$} & $28.94 \pm 0.78^{\mathrm{c}}$ \\
\hline SQ & $125.51 \pm 7.32 \mathrm{a}$ & \multicolumn{2}{|c|}{$415.95 \pm 25.63^{\mathrm{b}}$} & $39.64 \pm 2.67^{b}$ \\
\hline SB & $112.08 \pm 4.68 \mathrm{~b}$ & \multicolumn{2}{|c|}{$277.81 \pm 4.83^{c}$} & $47.18 \pm 02.19^{\mathrm{a}}$ \\
\hline \multirow{2}{*}{ Region } & \multicolumn{4}{|c|}{ Microelements } \\
\hline & $\mathrm{Mn}$ & $\mathrm{Fe}$ & $\mathrm{Zn}$ & $\mathrm{Cu}$ \\
\hline OUL & $1.55 \pm 0.08^{\mathrm{d}}$ & $22.03 \pm 0.95^{\mathrm{b}}$ & $9.32 \pm 0.38^{d}$ & $0.36 \pm 0.05^{\mathrm{c}}$ \\
\hline OUJ & $1.17 \pm 0.07^{\mathrm{e}}$ & $19.80 \pm 0.64^{\mathrm{b}}$ & $14.51 \pm 0.47^{\mathrm{a}}$ & $0.58 \pm 0.05^{\mathrm{b}}$ \\
\hline $\mathrm{CH}$ & $2.79 \pm 0.12^{\mathrm{b}}$ & $29.76 \pm 0.59^{\mathrm{a}}$ & $11.07 \pm 0.64^{\mathrm{b}, \mathrm{c}}$ & $1.21 \pm 0.10^{\mathrm{a}}$ \\
\hline $\mathrm{BM}$ & $2.03 \pm 0.09^{c}$ & $21.84 \pm 0.99^{b}$ & $9.75 \pm 0.48^{\mathrm{c}, \mathrm{d}}$ & $0.68 \pm 0.09^{\mathrm{b}}$ \\
\hline BA & $5.07 \pm 0.2^{\mathrm{a}}$ & $23.12 \pm 0.84^{\mathrm{b}}$ & $10.35 \pm 0.30^{\mathrm{b}, \mathrm{c}, \mathrm{d}}$ & $0.39 \pm 0.05^{\mathrm{c}}$ \\
\hline SQ & $1.70 \pm 0.11^{\mathrm{c}, \mathrm{d}}$ & $10.34 \pm 0.81^{\mathrm{d}}$ & $10.85 \pm 0.53^{\mathrm{b}, \mathrm{c}}$ & $0.12 \pm 0.03^{\mathrm{d}}$ \\
\hline SB & $1.57 \pm 0.09^{\mathrm{d}}$ & $16.55 \pm 1.96^{\mathrm{c}}$ & $11.32 \pm 0.43^{b}$ & $0.14 \pm 0.02^{\mathrm{d}}$ \\
\hline
\end{tabular}

Data are expressed as means \pm Standard Error (SE); All measurements are analyzed in triplicate $(n=3)$; SE: Standard Error; The values in the same column with different letters differs significantly at $p<0.05$

Based on the current study results of nutritional composition, particularly for protein $(7.17 \mathrm{~g} / 100 \mathrm{~g})$, dietary fiber $(17.06 \mathrm{~g} / 100$ $\mathrm{g}$ ), and ash content (4.03 g/100g) (Table 2; Figure 2), and in comparison, with the feed quality recommended by Rogosic et al. (2006), the leaves of Moroccan A. unedo could be considered intermediate quality feed. Regarding the differences observed in these parameters over surveyed regions, we can conclude that shrubs grown in the BM and OUJ region seem very promising considering their high protein, carbohydrates, dietary fiber, fat, total sugar, and ash concentrations that may contribute significantly to their nutritive value. Results of the current study provide a comprehensive nutrition profile of Moroccan A. unedo. This study also highlighted the geographic variation in nutrients and mineral composition. Therefore, it is the first step of diversity studies planned for a wide valorization of this species and to establish further works to deepen and extend investigations on new functional products from this plant.

\subsection{Chemical variability}

The PCA and FDA established the variability within 120 individual trees. The PCA was performed on $\mathrm{pH}$, moisture content $(\mathrm{TH})$, protein (TP), carbohydrates (Tgl), total sugar (TST), reducing sugar (TSR), dietary fiber (TF), ash content (TC), fat matter (TMG) and energetic value (VE). The results demonstrate a considerable variability among investigated leaf samples in their contents of the major chemical component across the surveyed regions, and they are in the line with the results reported in our previous study about the nutritional value and mineral composition variability of Moroccan A. unedo fruits collected from the same locations (Ait lhaj et al., 2021a).

The data presented in Figure 2 shows the individual distribution in the space of the first two principal components (PC1 + PC2). These latter explained cumulatively $60.4 \%$ of the total variation. The first principal component $39.99 \%$ total variation of the analysis) was mostly correlated with the dry matter, reducing sugar, and energetic value, while it was correlated negatively with protein content. The second principal component $(20.41 \%$ total variation of the data) was correlated with moisture, $\mathrm{pH}$, ash, dietary fiber, and protein content. Concerning PC1, samples from $\mathrm{CH}$ have strong positive scores, indicating that they are characterized by a high amount of dry matter, reducing sugar and energetic value, and appreciable content of total sugar, fat, and carbohydrates. On the opposite, OUL, SB, and SQ samples recorded low scores of these compounds.

For PC2, almost all of the samples from BM, OUJ regions showed high positive scores, implying their high fiber, ash, fat, protein, and total sugar contents. All SB samples showed the highest negative scores. These samples were characterized by low nutritive value (Figure 2). 


\begin{tabular}{|c|c|c|c|c|c|c|c|}
\hline BA & 0 & & & & & & \\
\hline BM & 29.49 & 0 & & & & & \\
\hline $\mathrm{CH}$ & 46.99 & 50.17 & 0 & & & & \\
\hline OUJ & 32.57 & 31.37 & 64.7 & 0 & & & \\
\hline OUL & 4.38 & 39.18 & 35.94 & 47.23 & 0 & & \\
\hline SB & 20.29 & 51.88 & 55.47 & 43.91 & 27.91 & 0 & \\
\hline \multirow[t]{2}{*}{ SQ } & 7.57 & 44.05 & 40.65 & 38.25 & 6.32 & 18.75 & 0 \\
\hline & BA & $\mathrm{BM}$ & $\mathrm{CH}$ & OUJ & OUL & SB & SQ \\
\hline
\end{tabular}

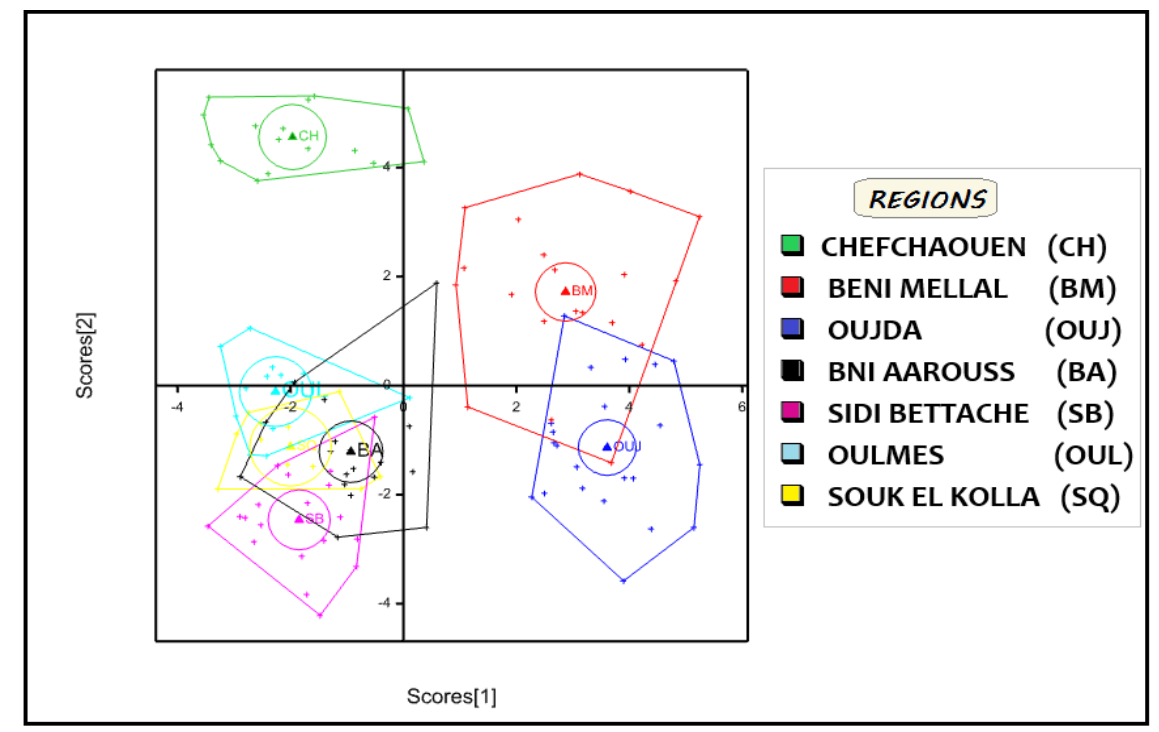

Figure 3 Scatter plot for factorial discriminate analysis of the 120 A. unedo samples from seven regions

As expected, there was a chemical variation among the regions studied. Individuals from $\mathrm{CH}$ samples belong to the same group. The chemical dissimilarity between $\mathrm{CH}$ and other regions was very high with Mahalanobis distances of 64.7, 55.47, 50.17, 46.99, 40.65, and 35.94 for OUJ, SB, BM, BA, SQ, and OUL, respectively. On the contrary, short distances were recorded between BA, SQ, and OUL, which reflect high chemical similarity (Table 5).

The results reported in Figure 3 were displayed the quantitative heterogeneity of wild Moroccan A. unedo and showed high variability within the individual trees. The following groups have been defined (Table 6):

Group I (GI): This group is represented by 45 samples $(37.5 \%$ of samples) and characterized by its considerable amount of crude fiber $(15.68-23.22, \mathrm{M}=17.99 \mathrm{~g} / 100 \mathrm{~g} \mathrm{DW})$ and total protein (5.43 - 9.31, M = 7.02 g/100g DW). Individuals from BA, SQ, and OUL, which belong to this group, were characterized by an average nutritive value. Two individuals from the Dazia location in the BA region have recorded the highest protein content of all samples, Dazia 2 (9.25 g/100g DW) and Dazia $3(9.38 \mathrm{~g} / 100 \mathrm{~g}$ DW).

Group II (GII): This group represents $15.8 \%$ of samples and shows low content of crude fiber $(10.21-15.25, \mathrm{M}=12.9 \mathrm{~g} / 100 \mathrm{~g}$ DW), fat (6.36- 8.41, M=7.28 g/100g DW), total sugar (10.4122.31, $\mathrm{M}=15.01 \mathrm{~g} / 100 \mathrm{~g} \mathrm{DW})$ and ash $(2.24-4.05, \mathrm{M}=3.23 \mathrm{~g} / 100 \mathrm{~g}$ $\mathrm{DW})$. Almost all SB samples have belonged to this group, which is distinguished by the lowest nutritional value.

Group III (GIII):This group contains 40 samples $(33.3 \%$ of samples); crude fiber (14.15-20.45, M=18.07), total protein (5.70$8.78, \mathrm{M}=7.4 \mathrm{~g} / 100 \mathrm{~g} \mathrm{DW})$, fat $(7.01-12.48, \mathrm{M}=9.55 \mathrm{~g} / 100 \mathrm{~g}$ DW), total sugar (12.33-36.62, $\mathrm{M}=23.61 \mathrm{~g} / 100 \mathrm{~g} \mathrm{DW})$, reducing sugar (3.01-10.96, M=5.12 g/100g DW) and ash (2.81- 6.63, $\mathrm{M}=$ $4.33 \mathrm{~g} / 100 \mathrm{~g} \mathrm{DW})$ were the most relevant components. One sample from OUJ has recorded the highest content of protein (TF2, 9.07 $\mathrm{g} / 100 \mathrm{~g} \mathrm{DW})$. Almost all individuals who belonged to this group are from BM and OUJ regions, which may be qualified as A. unedo leaves with high nutritional value. 
Table 6 Summary of the variation in the chemical composition and the classification of harvest samples across groups by using factorial discriminant analysis

\begin{tabular}{|c|c|c|c|c|c|c|c|c|}
\hline \multirow[b]{2}{*}{ Variables } & \multicolumn{4}{|c|}{ Group I (N=45) } & \multicolumn{4}{|c|}{ Group II (N=19) } \\
\hline & mean & SE & Min & $\operatorname{Max}$ & mean & SE & Min & Max \\
\hline Dry matter & 89.36 & 0.10 & 87.08 & 90.76 & 90.45 & 0.39 & 88.08 & 92.89 \\
\hline Ashes & 4.15 & 0.09 & 3.00 & 5.67 & 3.23 & 0.12 & 2.24 & 4.05 \\
\hline Protein & 7.02 & 0.14 & 5.43 & 9.31 & 7.00 & 0.09 & 6.02 & 7.94 \\
\hline $\mathrm{pH}$ & 4.72 & 0.03 & 4.39 & 5.50 & 4.88 & 0.03 & 4.66 & 5.13 \\
\hline Crude fiber & 17.99 & 0.20 & 15.68 & 23.22 & 12.90 & 0.36 & 10.21 & 15.25 \\
\hline Fat & 8.17 & 0.12 & 6.45 & 10.07 & 7.28 & 0.12 & 6.36 & 8.41 \\
\hline Total sugar & 19.282 & 0.45 & 13.33 & 27.76 & 15.01 & 0.81 & 10.41 & 22.31 \\
\hline Reducing sugar & 3.37 & 0.23 & 0.96 & 8.56 & 4.11 & 0.33 & 1.22 & 7.31 \\
\hline Moisture & 10.63 & 0.10 & 9.24 & 12.92 & 9.54 & 0.39 & 7.11 & 11.92 \\
\hline Carbohydrates & 70.12 & 0.21 & 66.90 & 72.41 & 72.93 & 0.45 & 69.74 & 76.19 \\
\hline Energetic value & 381.78 & 0.85 & 369.83 & 396.08 & 385.27 & 1.44 & 376.05 & 398.48 \\
\hline \multirow[b]{2}{*}{ Variables } & \multicolumn{4}{|c|}{ Group III ( $N=40)$} & \multicolumn{4}{|c|}{ Group IV (N=16) } \\
\hline & mean & SE & Min & $\operatorname{Max}$ & mean & SE & Min & Max \\
\hline Dry matter & 91.76 & 0.18 & 89.81 & 93.97 & 94.82 & 0.15 & 93.64 & 95.90 \\
\hline Ashes & 4.33 & 0.15 & 2.81 & 6.63 & 3.83 & 0.10 & 3.05 & 4.56 \\
\hline Protein & 7.40 & 0.12 & 5.70 & 8.78 & 5.41 & 0.14 & 4.15 & 6.13 \\
\hline $\mathrm{pH}$ & 5.18 & 0.04 & 4.61 & 5.89 & 4.47 & 0.05 & 4.23 & 4.94 \\
\hline Crude fiber & 18.07 & 0.26 & 14.15 & 20.45 & 16.87 & 0.27 & 14.61 & 18.84 \\
\hline Fat & 9.55 & 0.23 & 7.01 & 12.48 & 9.6 & 0.26 & 7.87 & 11.58 \\
\hline Total sugar & 23.61 & 0.72 & 12.33 & 36.62 & 26.14 & 0.67 & 21.34 & 31.41 \\
\hline Reducing sugar & 5.12 & 0.23 & 3.01 & 10.96 & 6.96 & 0.43 & 4.32 & 10.71 \\
\hline Moisture & 8.23 & 0.18 & 6.03 & 10.19 & 5.17 & 0.15 & 4.10 & 6.36 \\
\hline Carbohydrates & 71.17 & 0.29 & 66.63 & 75.11 & 75.97 & 0.26 & 74.16 & 78.31 \\
\hline Energetic value & 400.31 & 1.21 & 383.16 & 412.69 & 411.97 & 1.79 & 398.71 & 427.85 \\
\hline
\end{tabular}

Group IV (GIV): This group consists of 16 individuals, having the richest content of total sugar (21.34-31.41, M=26.14 g/100g DW) and carbohydrates (74.16-78.31, M= $75.97 \mathrm{~g} / 100 \mathrm{~g} \mathrm{DW})$, and presented the lowest proportion of protein with an average of 5.41 $\mathrm{g} / 100 \mathrm{~g}$ DW. It is noticeable that all the samples collected from the Chefchaouen area $(\mathrm{CH})$ belonged to this group. A. unedo of this area has good nutritional value but is a little bit lower than the group III.

\section{Conclusion}

In conclusion, almost all of the A. unedo leaf samples studied, taken from 15 locations covering seven regions of Morocco, showed a rich chemical composition, alongside their important macro and micro-mineral levels. That makes this plant a good candidate for livestock feeding, especially during the arid season and the hot season, especially by using feed additives such as activated carbon and calcium hydroxide, which have a potent effect on the availability of bioactive compounds in the animal organism. The PCA analysis revealed high variation among and within regions, confirming the considerable effect of location on plant composition and its role during the realization of nutritional studies. This is the first paper concerning an in-depth study on the native populations of $A$. unedo, providing fundamental data to promote a national program on the valorization and domestication of this species by the selection of the most valuable and performant 
genotypes. However, further research on genetic diversity and bioactive compounds content in leaves is planned to complete our study. Regarding its chemical composition, further study about other anti-nutritional factors (phytate, oxalate, and saponin) in the A. unedo leaves is required, as well as the realization of experiments on ruminants to evaluate their taste quality and productivity.

\section{Acknowledgements}

The authors would like to thank the staff of the National Institute of Agricultural Research (INRA) (Rabat, Morocco) for their precious help.

\section{Conflict of interest}

No potential conflict of interest was reported by the authors

\section{References}

Ait lhaj Z ZA, Abboussi O, Ibork H, Diria G, Bakhy K, Bchitou R (2021a) Influences of soil physico-chemical characteristics on the mineral composition of the Moroccan strawberry. Journal of Experimental Biology and Agricultural Sciences 9(3): 294 - 304.

Ait lhaj Z, Bchitou R, Gaboun F, Abdelwahd R, Benabdelouahab T, Kabbour MR, Pare P, Diria G, Bakhy K (2021b) Moroccan Strawberry Tree (Arbutus unedo L.) Fruits: Nutritional Value and Mineral Composition. Foods 10:2263.

Amiri F (2012) Comparison of nutritive values of grasses and legume species using forage quality index. Songklanakarin Journal of Science \& Technology 34 (5): 577-586.

Ammar H, Lopez S, Gonzalez J (2005) Assessment of the digestibility of some Mediterranean shrubs by in vitro techniques. Animal Feed Science and Technology 119:323-331.

AOAC (1990) Official methods of analysis. Association of Official Analytical Chemists 881-882.

AOAC (2000) Official Methods of Analysis of AOAC INTERNATIONAL,. The association of official Analytical Chemists 17th.

AOAC (2005) Official Methods of Analysis of AOAC Official Method 200508 18th edn.

Asmaa N, Abdelaziz G, Boulanouar B, Carbonell-Barrachina ÁA, Cano-Lamadrid M, Noguera-Artiaga L (2021) Chemical composition, antioxidant activity and mineral content of Arbutus unedo (Leaves And Fruits). Journal of Microbiology, Biotechnology and Food Sciences 8(6):1335-1339.
Barros L, Venturini BA, Baptista P, Estevinho LM, Ferreira IC (2008) Chemical composition and biological properties of portuguese wild mushrooms: a comprehensive study. Journal of Agricultural and Food Chemistry 56:3856-3862.

Boubaker A, Buldgen A, Kayouli C (2004) Composition chimique et teneur en composés phénoliques des espèces arbustives du Nord-Ouest de la Tunisie. Ferchichi A(comp), Ferchichi A(collab) Réhabilitation des pâturages et des parcours en milieux méditerranéens Options Méditerranéennes 62:315-317.

Boussalah N, Boussalah D, Cebadera-Miranda L, Fernández-Ruiz V, Barros L, Ferreira IC, Sanchez Mata M, Madani K (2018) Nutrient composition of Algerian strawberry-tree fruits (Arbutus unedo L.).Fruits 73(5):283-297.

Canadell J, López-Soria L (1998) Lignotuber reserves support regrowth following clipping of two Mediterranean shrubs. Functional Ecology 12:31-38.

Celikel G, Demirsoy L, Demirsoy H (2008) The strawberry tree (Arbutus unedo L.) selection in Turkey. Scientia Horticulturae 118:115-119.

Chemists AAOOA (1999) Official Methods of Analysis. Association of Official Analytical Chemists: .

Delgado-Pelayo R, Gallardo-Guerrero L, Hornero-Méndez D (2016) Carotenoid composition of strawberry tree (Arbutus unedo L.) fruits. Food Chemistry 199:165-175.

Dubois M, Gilles KA, Hamilton JK, Rebers Pt, Smith F (1956) Colorimetric method for determination of sugars and related substances. Analytical Chemistry 28:350-356.

Gaouar N (2011) Etude de la valeur nutritive de la caroube de différentes variétés Algériennes. Mémoire de Magister Université Abou Bekr Belkaid Tlemcen Algérie. Retrieve from http://dspace.univ-tlemcen.dz/bitstream/112/304/1/Etude-de-lavaleur-nutritive-de-la-caroube-de-differentes-varietesAlgeriennes.pdf acess on 29th April 2021.

García AN, Árias SdPB, Morte A, Sánchez-Blanco MJ (2011) Effects of nursery preconditioning through mycorrhizal inoculation and drought in Arbutus unedo L. plants. Mycorrhiza 21:53-64.

Gündoğdu M, Ercisli S, Canan I, Orman E, Sameeullah M, Naeem M, Ayed RB (2018) Diversity in phenolic compounds, biochemical and pomological characteristics of Arbutus unedo fruits. Folia Horticulturae 30:139.

INRA - Nifar (2011) Annual report. Available at https://www.inra.org.ma/sites/default/files/docs/rapactivites/rapacti vites11en.pdf access on 29th April 2021. 
Jardim C, Macedo D, Figueira I, Dobson G, McDougall GJ, Stewart D, Ferreira RB, Menezes R, Santos CN (2017) (Poly) phenol metabolites from Arbutus unedo leaves protect yeast from oxidative injury by activation of antioxidant and protein clearance pathways. Journal of Functional Foods 32:333-346.

Kováčik J, Klejdus B, Hedbavny J, Štork F, Bačkor M (2009) Comparison of cadmium and copper effect on phenolic metabolism, mineral nutrients and stress-related parameters in Matricaria chamomilla plants. Plant and Soil 320:231-242.

Li TS, Mazza G (1999) Correlations between leaf and soil minera concentrations and ginsenoside contents in American ginseng HortScience 34:85-87.

Miller GL (1959) Use of dinitrosalicylic acid reagent for determination of reducing sugar. Analytical Chemistry 31:426-428.

Mrabti HN, Marmouzi I, Sayah K, Chemlal L, El Ouadi Y, Elmsellem H, Cherrah Y, Faouzi MA (2017) Arbutus unedo L aqueous extract is associated with in vitro and in vivo antioxidant activity. Journal of Materials and Environmental Sciences 8:217-224.

Nunes RJDS (2017) Micromedronho: design of microencapsulated arbutus unedo leaves and fruits by spray drying for supplements and functional foods. vol. doctor in Biotechnological sciences, specialty of food biotechnolog Portugal: UNIVERSIDADE DO ALGARVE. Retrieve from http://hdl.handle.net/10400.1/10796 access on 29th April 2021.

Özcan MM, Hacıseferoğulları H (2007) The strawberry (Arbutus unedo L.) fruits: chemical composition, physical properties and mineral contents. Journal of Food Engineering 78:1022-1028.

Parissi ZM, Abraham EM, Roukos C, Kyriazopoulos AP, Petridis A, Karameri E (2018) Seasonal quality assessment of leaves and stems of fodder ligneous species. Notulae Botanicae Horti Agrobotanici Cluj-Napoca 46:426-434.

Penuelas J, Sardans J, Ogaya R, Estiarte M (2008) Nutrient stoichiometric relations and biogeochemical niche in coexisting plant species: effect of simulated climate change. Polish Journal of Ecology 56:613-622.

Rajagopal D, Mathew M (2020) Role of Arabidopsis RAB5 GEF vps9a in maintaining potassium levels under sodium chloride stress. Plant Direct 4:e0273.
Rogosic J, Pfister J, Provenza FD, Grbesa D (2006) Sheep and goat preference for and nutritional value of Mediterranean maquis shrubs. Small Ruminant Research 64:169-179.

Ruiz-Rodríguez B-M, Morales P, Fernández-Ruiz V, SánchezMata M-C, Camara M, Díez-Marqués C, Pardo-de-Santayana M, Molina M, Tardío J (2011) Valorization of wild strawberry-tree fruits (Arbutus unedo L.) through nutritional assessment and natural production data. Food Research International 44:12441253.

Saleem M, Durani AI, Alharthy RD, Ahmed M, Shafiq MI, Hameed A, Hussain SM, Bashir W (2021) Ultrasound Assisted Extraction of Micro and Macroelements in Fruit Peels Powder Mineral Supplement for Osteoporosis Patients and their Determination by Flame Atomic Absorption Spectrometry. DOI: https://doi.org/10.21203/rs.3.rs-733194/v1.

Santiso Carral X (2015) Genetic structure and geographic variation in ecophysiological traits of Arbutus unedo L. Retrieve from http://hdl.handle.net/10347/13623 access on 29th April 2021.

Stephenie S, Chang YP, Gnanasekaran A, Esa NM, Gnanaraj C (2020) An insight on superoxide dismutase (SOD) from plants for mammalian health enhancement. Journal of Functional Foods 68:103917.

Takrouni MM, Boussaid M (2010) Genetic diversity and population's structure in Tunisian strawberry tree (Arbutus unedo L.). Scientia Horticulturae 126:330-337.

Tisserand J, Faurie F (1994) Compared ruminal degradability in cows and sheep of the crude protein of Mediterranean forages and by-products. In: 1 Rencontres recherches ruminants, Paris (France), 1-2 Dec 1994: Institut de l'Elevage.

Udo M, Ekpo U, Ahamefule F (2018) Effects of processing on the nutrient composition of rubber seed meal. Journal of the Saudi Society of Agricultural Sciences 17:297-301.

Zitouni H, Hssaini L, Messaoudi Z, Ourradi H, Viuda-Martos M, Hernández F, Ercisli S, Hanine H (2020) Phytochemical components and bioactivity assessment among twelve strawberry (Arbutus unedo L.) genotypes growing in Morocco using chemometrics. Foods 9:1345. 